\title{
Microfungal Community in Sandy Beaches Located in Kedah, Pahang and Sabah, Malaysia
}

\author{
Salleh SL, Raup R, Azman N and Mohd Zainudin NAI
}

Department of Biology, Faculty of Science, Universiti Putra Malaysia, 43400 Serdang, Selangor, Malaysia

Salleh SL, Raup R, Azman N, Mohd Zainudin NAI 2018 - Microfungal Community in Sandy Beaches Located in Kedah, Pahang and Sabah, Malaysia. Studies in Fungi 3(1), 321-332, Doi $10.5943 / \mathrm{sif} / 3 / 1 / 32$

\begin{abstract}
Microfungi are fundamental organisms help in balancing the ecosystem. The aims of this study are to identify microfungi isolated from sandy beaches based on internal transcribed spacers (ITS) sequence analysis and to determine the phylogenetic relationship among the locations of sampling areas. Fifty-seven isolates of microfungi were obtained from six beaches located in Kedah (Chenang Beach), Pahang (Balok Beach) and Sabah (Mamutik Island, Manukan Island, Sapi Island and Tanjung Aru Beach) to be used in this study. From the finding, the highest identified species were Aspergillus species (27 isolates) followed by Trichoderma species (12 isolates), Penicillium species (10 isolates), Fusarium species (6 isolates), Bipolaris species (1 isolate) and Chaetomium species (1 isolate). ITS fragment of all isolates was amplified in within the size range of 533-658 bp. A phylogenetic tree was constructed using maximum likelihood (ML) method; the isolates were grouped into three clades according to their classes. In conclusion, diverse microfungi isolated from sandy beach soil depicting 19 species were discovered. Future studies are highly recommended to focus on intra- and interspecies diversity based on microsatellite markers analysis, consequently the originality and distribution of the fungal isolates. The outcome of this study includes a baseline data on the occurrence and species-diversity as well as important information on the status of microfungi in Malaysia beaches located in Kedah, Melaka and Sabah. It can be used as a checklist for future studies related to fungi distribution in the tropical beaches.
\end{abstract}

Key words - Ecology - environmental mycology - fungi - identification - microbial phylogenetics

\section{Introduction}

Beach is a reservoir for microfungi including Ascomycetes that act as decomposers that retain sand ecosystem. However, concern had arose when a number of beachgoers were seen increasing. The predicted possibilities of decreased or increased microfungi diversity in the sandy beach soil could indicate some current situations and threat of health to the beachgoers by the pathogenic microfungi. This study will provide an information or inventory on the ecology and distribution of microfungi as well as early prediction on the conditions of particular beaches, which can improve the efficiency of beach management. Sabino et al. (2014) collected growing evidence that microbes including fungi could be harmful to humans in various beach sands worldwide and often in concentrations greater than the beach water. Even though there were few cases reported regarding this pathogenic microbe on public health, consideration should be made on people often exposed to 
the beach through professional activities since there is a high risk for them to face health problems from the pathogenic microbes. Other than pathogenic effect, some microfungi in sandy beach soil can also be considered as a source of industrial products with the ability to balance the ecosystem biotic elements. Exploring the species diversity of microfungi in sandy beach soil, there is a possibility to harvest microfungi of interest from sandy beach soil to be used as a source for industrial production or with commercial potential.

Discovering the diversity of microfungi in sandy beach soil is important to find a source of microfungi-based industrial products, for us to appreciate their existence in maintaining ecosystem stability, introduce new biological indicator from microfungi and most importantly to make aware on the existence of potentially pathogenic fungi. In the meantime, some researchers suggested that the potential public health issues concerning both sand and water quality of beaches should be considered in future policy decisions (Sabino et al. 2014).

To date, there have been no comprehensive reports on microfungi isolated from sandy beach soil in Malaysia except in Penang Island by Zakaria et al. (2011), Teh \& Latiffah (2015). However, studies on the diversity of soil microfungi in sandy beach ecosystem of Malaysia as well as other Asian countries are still limited. Thus, renowned beaches or islands were aimed in this study since they are often visited by beachgoers and most well-known by tourists and local people in Malaysia. These beaches include Balok Beach in Pahang, Langkawi Island in Kedah and another four islands in Sabah comprising Mamutik Island, Sapi Island, Manukan Island and Tanjung Aru beach. Discovering the diversity and distribution of microfungi present in sandy beach soil in Malaysia can give significant information on Malaysian beaches mycoflora, which is useful for an efficient management of the beach ecosystem, raising awareness concerning public health on beach and to be used in various fields of science.

This study was conducted with findings that can be used as references for the future studies and to give an idea on the diversity of microfungi from the six selected areas. The objectives of this study are to isolate and identify the microfungi isolates obtained from sandy beaches based on Internal Transcribed Spacers (ITS) sequence analysis and to determine the phylogenetic relationship among isolated fungi from various locations.

\section{Materials \& Methods}

\section{Sampling and fungal isolation}

Six commercialised beaches in Malaysia located at Kedah, Pahang, and Sabah were selected namely Chenang Beach, Balok Beach, Manukan Island, Mamutik Island, Sapi Island and Tanjung Aru Beach (Fig. 1). All beaches are flooded with locals and international tourists annually, which contribute to anthropic pressure of the beaches. In each sampling area, five sand samples were collected at five points $5 \mathrm{~m}$ apart. Sand sample was scraped from surface down to $10 \mathrm{~cm}$ depth at a foreshore zone. Sand samples from each point were put in a specimen bottle and labelled according to the collection site. They were kept in refrigerator at $4{ }^{\circ} \mathrm{C}$ until further use.

About $2 \mathrm{~g}$ of sand sample was sprinkled onto potato dextrose agar (PDA) plate using a sterile spatula and labelled according to site of collection. The primary culture was observed daily for 7 days for growth of fungal colony. All visible fungal colonies immediately transferred to a new PDA plate to avoid overlapping from other colonies. Hyphal tipping technique was performed to obtain pure culture of a single colony (Leslie \& Summerell 2006). After 24 hours, a dissecting microscope was used to find a single hyphal tip. The targeted single hyphae from the culture was cut out using a sterile scalpel from the hyphal tip and transferred onto a new PDA plate. The pure isolates were grown on PDA plates and incubated at room temperature under standard conditions for 5 days. The cultures were then used for DNA extraction.

\section{DNA extraction}

All isolated fungal were cultured on PDA plate, which was then incubated for 5 days under 8 hours light and 16 hours dark at $28 \pm 2{ }^{\circ} \mathrm{C}$. The pure fungal culture obtained was put on DNA 
extraction. Genomic DNA of pure culture was extracted using UltraClean ${ }^{\circledR}$ Microbial DNA Isolation Kit (MO BIO, Carlsbad, CA, USA) following the manufacturer's protocol. The $50 \mu 1$ gDNA of each fungal isolated was obtained and stored in $-20^{\circ} \mathrm{C}$ freezer for further use.

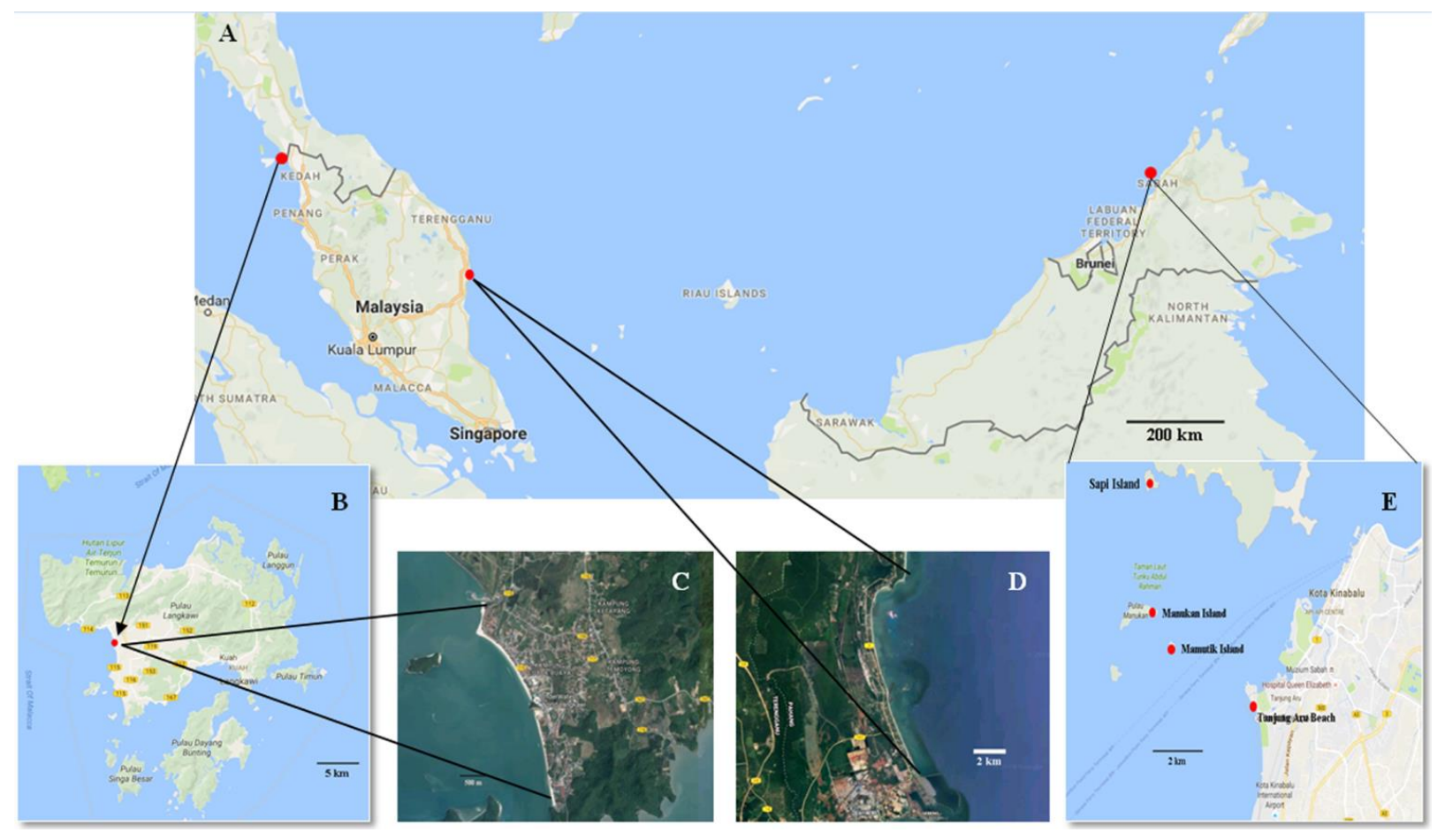

Fig. 1 - The map of sampling sites with red dotted. A Malaysia map. B Langkawi Island map. C Shore of Chenang Beach. D Shore of Balok Beach, Pahang. E Map of Sapi Island, Mamutik Island, Manukan Island and Tanjung Aru Beach in Sabah.

\section{Gel electrophoresis}

Each PCR products was gel electrophoresed by mixing $0.3 \mathrm{~g}$ of agarose powder with $20 \mathrm{ml}$ of TBE buffer to make a final concentration of $1.5 \%$. The cooled agarose gel was placed in the gel electrophoresis box with buffer solution poured onto it. DNA was inserted into the holes and a 100 bp DNA ladder was used. The voltage was set at $90 \mathrm{~V}$ for 30-40 mins. The gel was visualized under a UV trans-illuminator to view the amplicon size. The successful amplification of ITS region was observed between 500 to $700 \mathrm{bp}$. Next, gel purification was carried out to obtain the purified ITS regions.

\section{Gel purification and sequencing}

All PCR products were purified using QIAquick Gel Extraction Kit (QIAGEN, USA) following the manufacturer's instructions. The DNA fragment was cut from gel with scalpel. Then, ratio of 3 to 1 was used to add 3 volumes of Buffer QG to one volume gel. The tube was incubated at $50^{\circ} \mathrm{C}$ for 10 mins until the gel was dissolved. Tube was vortexed for every two to three minutes to help dissolving the gel. Isopropanol was added to sample and mixed. Finally, the sample was added to QIAquick spin column. Then, the purified PCR products were sent for DNA sequencing using an Applied Biosystems 3730xl DNA Analyzer (MyTACG Bioscience Company, MY).

\section{Phylogenetic analysis and sequence deposition}

The sequences obtained were complemented and aligned. The sequencing alignments and phylogenetic tree analysis were performed using the Molecular Evolutionary Genetics Analysis (MEGA) 7.0 software. MEGA is one of the computer software for conducting statistical analysis on molecular evolution and for constructing phylogenetic trees (Kumar et al. 2016). All complemented sequences were BLAST at the GenBank database NCBI (https://blast.ncbi.nlm.nih.gov). 
Phylogenetic tree was constructed using Maximum Likelihood (ML) with test of phylogeny of Bootstrap method. Maximum likelihood is known to be a good statistical method for reconstructing sequence histories and uses a more complex evolution model (Blanchet 2014). The representative sequences of each species were obtained from GenBank and included in the tree. Saccharomyces cerevisiae was chosen as an out-group since it was classified in different class compared to all 57 isolates. All sequences were deposited in the GenBank database (gb-sub@ncbi.nlm.nih.gov) following the instructions.

\section{Results}

Fifty-seven isolates of Ascomycetes fungi were obtained from beach soil areas in Chenang Beach, Mamutik Island, Manukan Island, Sapi Island, Tanjung Aru Beach, and Balok Beach from sand beach soils samples comprising the genus Aspergillus, Bipolaris, Chaetomium, Fusarium, Penicillium and Trichoderma species. All the fungi isolates were identified based on ITS sequence analysis and deposited in the GenBank database (https://www.ncbi.nlm.nih.gov/genbank/) as tabulated in Table 1. Among 57 microfungal isolates, 27 isolates were dominated by Aspergillus species.

Table 1 Species of microfungi isolated from sandy beach in Kedah, Sabah and Pahang with their GenBank accession number.

\begin{tabular}{|c|c|c|c|c|}
\hline No. & $\begin{array}{l}\text { Isolate } \\
\text { Numbers }\end{array}$ & Locations & Taxa & $\begin{array}{l}\text { ITS GenBank } \\
\text { accession numbers }\end{array}$ \\
\hline 1 & $\mathrm{C} 2630$ & Balok Beach, Pahang & Trichoderma sp. & MG575503 \\
\hline 2 & $\mathrm{C} 2631$ & Balok Beach, Pahang & Aspergillus sp. & MG575518 \\
\hline 3 & $\mathrm{C} 2633$ & Balok Beach, Pahang & Trichoderma sp. & MG575504 \\
\hline 4 & $\mathrm{C} 2635$ & Balok Beach, Pahang & Penicillium sp. & MG575505 \\
\hline 5 & $\mathrm{C} 2636$ & Balok Beach, Pahang & Penicillium sp. & MG575506 \\
\hline 6 & C2639 & Balok Beach, Pahang & Penicillium sp. & MG575519 \\
\hline 7 & K2568 & Chenang Beach, Kedah & Bipolaris sp. & MG575499 \\
\hline 8 & K2569 & Chenang Beach, Kedah & Aspergillus sp. & MG575500 \\
\hline 9 & $\mathrm{~K} 2570$ & Chenang Beach, Kedah & Aspergillus sp. & MG549329 \\
\hline 10 & $\mathrm{~K} 2571$ & Chenang Beach, Kedah & Aspergillus sp. & MG575520 \\
\hline 11 & $\mathrm{~K} 2573$ & Chenang Beach, Kedah & Penicillium sp. & MG549330 \\
\hline 12 & K2574 & Chenang Beach, Kedah & Chaetomium sp. & MG575478 \\
\hline 13 & $\mathrm{~K} 2576$ & Chenang Beach, Kedah & Fusarium sp. & MG549331 \\
\hline 14 & K2579 & Chenang Beach, Kedah & Aspergillus sp. & MG575473 \\
\hline 15 & S2580 & Tanjung Aru Beach, Sabah & Aspergillus sp. & MG575490 \\
\hline 16 & S2582 & Tanjung Aru Beach, Sabah & Aspergillus sp. & MG575510 \\
\hline 17 & $\mathrm{~S} 2583$ & Tanjung Aru Beach, Sabah & Aspergillus sp. & MG575491 \\
\hline 18 & S2584 & Tanjung Aru Beach, Sabah & Trichoderma sp. & MG575492 \\
\hline 19 & S2585 & Tanjung Aru Beach, Sabah & Penicillium sp. & MG575497 \\
\hline 20 & S2587 & Sapi Island, Sabah & Aspergillus sp. & MG575501 \\
\hline 21 & S2588 & Sapi Island, Sabah & Aspergillus sp. & MG575481 \\
\hline 22 & $\mathrm{~S} 2590$ & Sapi Island, Sabah & Fusarium sp. & MG575493 \\
\hline 23 & S2591 & Sapi Island, Sabah & Penicillium sp. & MG575494 \\
\hline 24 & $\mathrm{~S} 2592$ & Sapi Island, Sabah & Aspergillus sp. & MG575511 \\
\hline 25 & S2593 & Sapi Island, Sabah & Trichoderma sp. & MG575512 \\
\hline 26 & S2594 & Sapi Island, Sabah & Fusarium sp. & MG575495 \\
\hline 27 & $\mathrm{~S} 2595$ & Sapi Island, Sabah & Aspergillus sp. & MG575513 \\
\hline 28 & S2596 & Sapi Island, Sabah & Aspergillus sp. & MG590099 \\
\hline 29 & S2597 & Sapi Island, Sabah & Aspergillus sp. & MG575496 \\
\hline 30 & S2598 & Mamutik Island, Sabah & Aspergillus sp. & MG575468 \\
\hline
\end{tabular}


Table 1 Continued.

\begin{tabular}{|c|c|c|c|c|}
\hline No. & $\begin{array}{l}\text { Isolate } \\
\text { Numbers }\end{array}$ & Locations & Taxa & $\begin{array}{l}\text { ITS GenBank } \\
\text { accession numbers }\end{array}$ \\
\hline 31 & S2599 & Mamutik Island, Sabah & Aspergillus sp. & MG575474 \\
\hline 32 & S2600 & Mamutik Island, Sabah & Aspergillus sp. & MG575479 \\
\hline 33 & S2601 & Mamutik Island, Sabah & Aspergillus sp. & MG575480 \\
\hline 34 & S2603 & Mamutik Island, Sabah & Trichoderma sp. & MG575507 \\
\hline 35 & S2604 & Mamutik Island, Sabah & Aspergillus sp. & MG575502 \\
\hline 36 & S2605 & Mamutik Island, Sabah & Aspergillus sp. & MG575469 \\
\hline 37 & S2606 & Mamutik Island, Sabah & Trichoderma sp. & MG575482 \\
\hline 38 & S2607 & Mamutik Island, Sabah & Aspergillus sp. & MG575470 \\
\hline 39 & S2608 & Mamutik Island, Sabah & Aspergillus sp. & MG575515 \\
\hline 40 & S2609 & Mamutik Island, Sabah & Aspergillus sp. & MG575483 \\
\hline 41 & S2610 & Mamutik Island, Sabah & Fusarium sp. & MG575484 \\
\hline 42 & S2611 & Mamutik Island, Sabah & Trichoderma sp. & MG575471 \\
\hline 43 & S2612 & Manukan Island, Sabah & Trichoderma sp. & MG575508 \\
\hline 44 & S2613 & Manukan Island, Sabah & Trichoderma sp. & MG575509 \\
\hline 45 & S2614 & Manukan Island, Sabah & Penicillium sp. & MG575485 \\
\hline 46 & S2615 & Manukan Island, Sabah & Penicillium sp. & MG575486 \\
\hline 47 & S2617 & Manukan Island, Sabah & Trichoderma sp. & MG575487 \\
\hline 48 & S2618 & Manukan Island, Sabah & Aspergillus sp. & MG575498 \\
\hline 49 & S2619 & Manukan Island, Sabah & Aspergillus sp. & MG575475 \\
\hline 50 & S2621 & Mamutik Island, Sabah & Penicillium sp. & MG575472 \\
\hline 51 & S2622 & Manukan Island, Sabah & Fusarium sp. & MG575488 \\
\hline 52 & S2623 & Manukan Island, Sabah & Fusarium sp. & MG575489 \\
\hline 53 & S2624 & Manukan Island, Sabah & Aspergillus sp. & MG575514 \\
\hline 54 & S2625 & Manukan Island, Sabah & Trichoderma sp. & MG575476 \\
\hline 55 & S2626 & Manukan Island, Sabah & Aspergillus sp. & MG575516 \\
\hline 56 & S2627 & Manukan Island, Sabah & Trichoderma sp. & MG575477 \\
\hline 57 & S2629 & Manukan Island, Sabah & Penicillium sp. & MG575517 \\
\hline
\end{tabular}

Colony of Bipolaris species K2568 showed black greyish pigment and black color of bottom surface in the PDA culture plate (Fig. 2). The colony of Chaetomium species isolate K2574 demonstrated white cottony on the PDA culture plate with circular form and did not produce pigmentation (Fig. 2).

The colony of Fusarium species appeared pale to white cottony mycelia on the upper surface while the lower surface showed no pigmentation. The culture plate was white, yellowish and pinkish, circular colony with entire margin (Fig. 2). The color of colony produced by Fusarium species S2590 was pinkish with yellowish pigmentation in its lower surface. Whereas Fusarium species isolates K2576, S2594 and S2622 produced white cottony mycelia with white pigmentation. Meanwhile, isolates S2610 and S2623 showed yellowish pigmentation on the lower surface with white color colony. Colony of Penicillium species on upper surface color was deep green, light green, brown and greyish green as shown in Fig. 2. The texture of colony was powdery with the presence of wrinkles on PDA. The whole colony shape was irregular and produced white followed by yellowish pigmentation. Colony of isolate C2635 identified as Penicillium species showed dark greyish color with white pigmentation in the lower surface (Fig. 2). In addition, Penicillium spp. produced green colony with greyish pigmentation for isolates S2585 and S2621 (Fig. 2). Isolates K2573 and S2615 identified as Penicillium species. displayed green colony with yellowish pigment (Fig. 2). The distribution of this colony was scattered around PDA. Isolates C2636 and S2591 produced light green colony with light yellow pigmentation, which were identified as Penicillium species. The colony of Trichoderma species was shown with green color 
in a circular shape with the entire margin shown in Fig. 2. Trichoderma isolates C2630, C2633, S2603, S2611, S2612, S2613, S2617, S2625 and S2627 showed the same features of colonies except for Isolate S2593 that produced different macromarphological characteristics (Fig. 2). Trichoderma species (isolates S2584 and S2606) showed green yellowish colony color with yellow pigmentation.

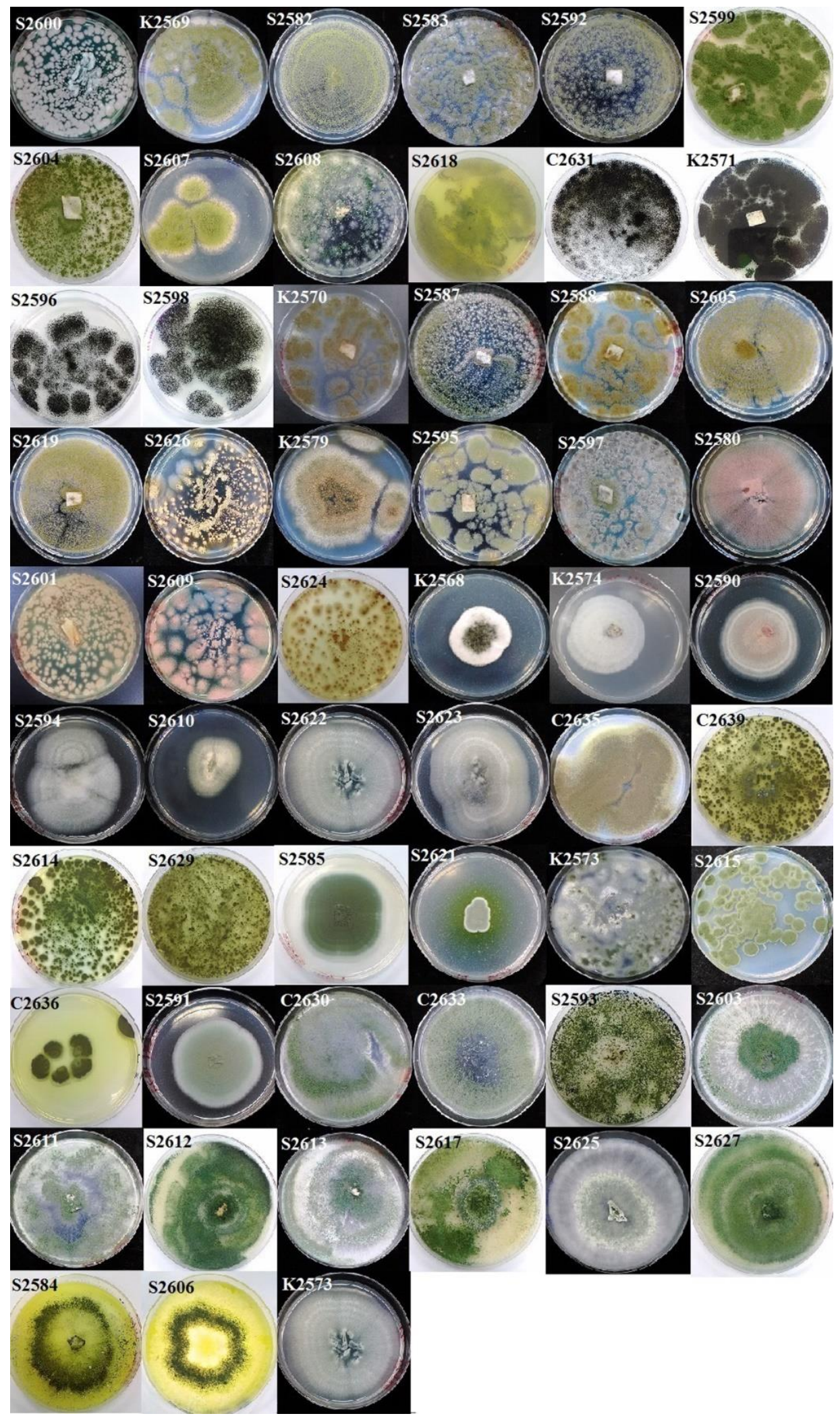

Fig. 2 - Colony features and pigmentation produced on PDA. 
The size of ITS fragment was at 500-700 bp (Fig. 3). Based on the BLAST search, ITS sequences showed high percentage of similarities from $97 \%$ to $100 \%$ with the GenBank database. After ITS sequences of each isolate were analyzed and BLAST on the GenBank, the range of size of Aspergillus species was 575 to $625 \mathrm{bp}$. Phylogenetic tree was constructed and analyzed based on ML with 1000 bootstrap replication using Tamura-Nei method.
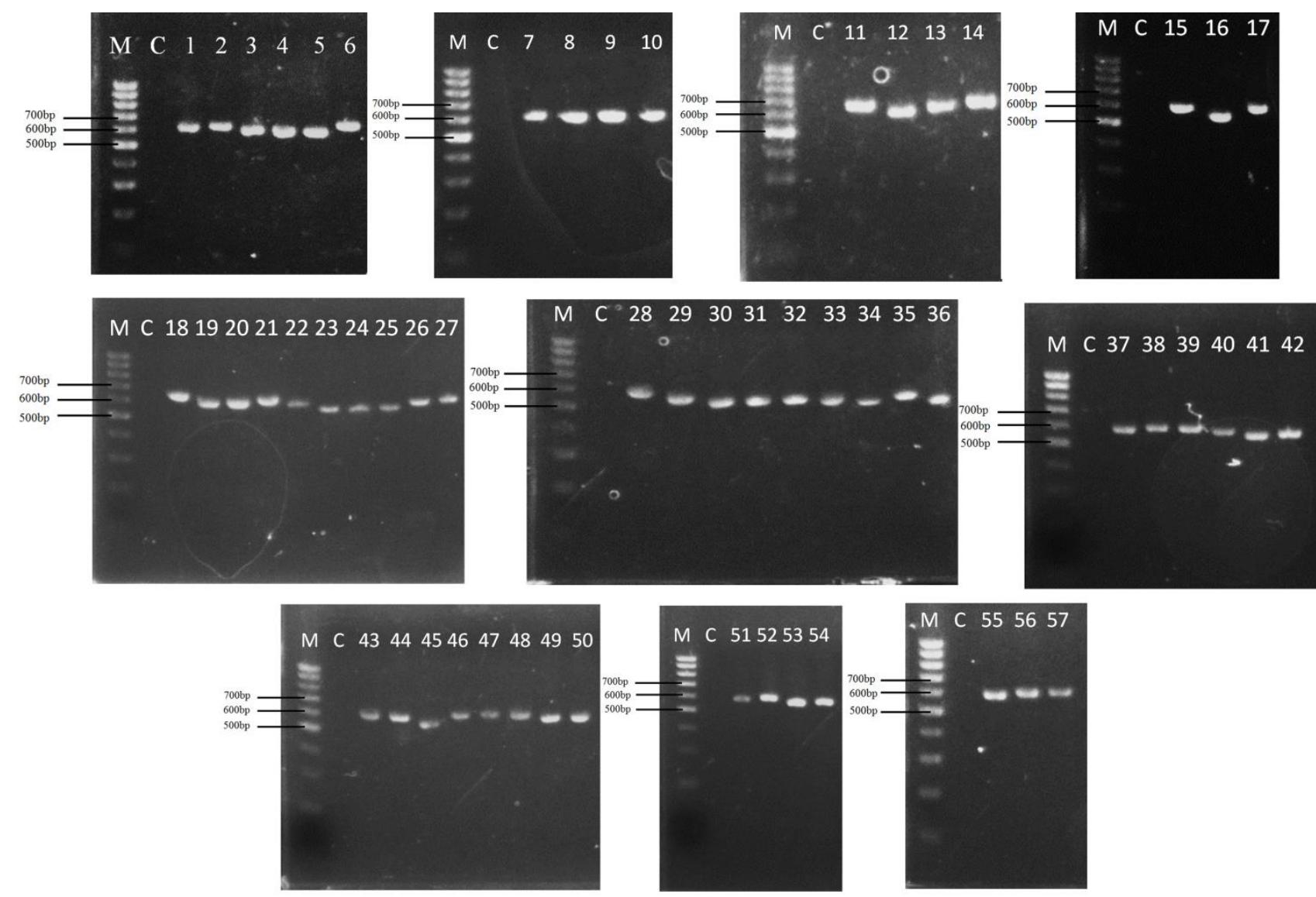

Fig. 3 - Banding patterns generated by primer ITS1 and ITS4 of each isolated fungi. Lanes left to right: 1) $\mathrm{K} 2573$, 2) $\mathrm{K} 2570$, 3) $\mathrm{K} 2576$, 4) $\mathrm{K} 2579$, 5) $\mathrm{K} 2571$, 6) S2625, 7) S2615, 8) S2621, 9) S2607, 10) S2598, 11) S2609, 12) S2610, 13) S2603, 14) S2606, 15) S2624, 16) S2595, 17) S2593. 18) $\mathrm{S} 2584$, 19) $\mathrm{S} 2585,20) \mathrm{S} 2583,21) \mathrm{S} 2580,22) \mathrm{S} 2591,23) \mathrm{S} 2594,24) \mathrm{S} 2590,25) \mathrm{S} 2597,26)$ S2588, 27) S2587, 28) K2569, 29) K2574, 30) S2599, 31) S2600, 32) S2601, 33) S2604, 34) S2623, 35) S2619, 36) S2614, 37) S2605, 38) S2611, 39) C2633, 40) C2631, 41) C2635, 42) C2636, 43) K2568, 44) S2608, 45) S2629, 46) S2627, 47) S2613, 48) S2617, 49) S2592, 50) S2582, 51) S2596, 52) C2630, 53) S2618, 54) S2626, 55) S2622, 56) S2612 and 57) C2629. M= 100 bp ladder. $\mathrm{C}=$ Control.

Fig. 4 illustrates the relationship of 57 isolates from microfungi isolated from beach soils in Kedah, Pahang, and Sabah. Based on molecular characterization, it was confirmed that out of 57 isolates, 27 isolates belonged to Aspergillus species. Meanwhile, 12 isolates belonged to Trichoderma species. Next, 10 isolates were identified as Penicillium species and was followed by six isolates of Fusarium species and one isolate for each genus of Bipolaris and Chaetomium.

The tree was divided into two branches known as clade I and clade II; Bipolaris species (Class Dothideomycetes) grouped in Clade II, apart from members of Class Eurotiomycetes and Sardariomycetes. Subclade A was grouped in Class Eurotiomycetes and was divided into A1 and A2; A1 consists of Aspergillus species and Penicillium species while A2 consists of only Penicillium species. Meanwhile, Class Sardariomycetes (Chaetomium species, Fusarium species and Trichoderma species) were classified in sub-clade B. Subclade B was divided into B1 and B2 
where B1 consists of Chaetomium species while B2 consists of Trichoderma species and Fusarium species. Saccharomyces cerevisiae (accession no: HW628115) was chosen as an outgroup as it belonged to different class of other genus.

\section{Discussion}

Aspergillus species was the dominant species and diverse in all six beaches in Sabah, Kedah and Pahang. By comparing to other studies, Zakaria et al. (2011) carried out a study on "Diversity of microfungi in sandy beach soil of Teluk Aling, Pulau Pinang" and based on their identification on morphologically, they found out seven genera known as Fusarium, Aspergillus, Trichoderma, Culvularia, Colletotrichum, Helminthosporum and Penicillium. Moreover, there was a new record of Penicilium pimiteouiense from beach soil in Malaysia, which reported by Teh \& Latiffah (2013). This sample was collected from sandy beach in Penang Island, which was identified based on the production of yellow on upper surface of the colonies and yellow to orange color on the lower surface.

Seelan et al. (2009) isolated Aspergillus species from mangrove forests in Borneo Island, Sarawak, Malaysia. Thirty-eight isolates belonged to five species of Aspergillus. The most common species found was Aspergillus flavipes. Teh \& Latifah (2015) carried out a study on Aspergillus species in beach sand located at Batu Ferringhi Beach, Penang. They stated that the presence of the species was probably due to presence of discarding organic litter and environmental factors including humidity necessary for the survival of the fungus and suitable temperature. This was because the sand particles provide microhabitat under specific conditions for the survival of conidia. According to Powell et al. (1994), Aspergillus cultures can rapidly grow on infertile and cheap substrates as well as secreting their own enzymes into a medium. Therefore, it is easier for them to culture. In addition, this genus is flexible and adaptive, thus capable of utilizing a wide range of substrates. Moreover, Bokulich \& Bamforth (2017) mentioned the ability of spores to disperse globally in air currents and to grow almost anywhere with appropriate food and water available. They also stated that when spores encounter a solid or liquid surface they would deposit and germinate if the conditions of moisture are optimum for growing.

This was followed by Trichoderma species with 12 isolates identified. This genus exists in all beaches studied except for Chenang Beach in Langkawi Island, Kedah. According to Asis \& Siddiquee (2016), many factors influence the distribution of Trichoderma species such as genetic structure, biological niches, soil type and geographical regions. Thus, this suggests that Chenang Beach do not favors the growth of Trichoderma species as the factors that influence the development of this species less in Chenang Beach.

There were 10 isolates of Penicillium species identified. Penicillium species was seen distributed in all beaches except for Mamutik Island in Sabah. Yee \& Zakaria (2014) isolated Pencillium georgiense from Batu Ferringhi Beach, Penang and confirmed it by morphological characteristics and phylogenetic analysis. On sandy beach, many factors determine the survival and dispersion of Penicillium species such as nature of the beach, tidal and season phenomena as well as animal and human activities (Zakaria et al. 2011).

Fusarium species were also identified, which located in four beaches in this study, which are Chenang Beach, Mamutik Island, Manukan Island, and Sapi Island while there are no Fusarium species found at Tanjung Aru Beach and Balok Beach. A study done by Zakaria et al. (2011) found seven genera of microfungi from Teluk Aling Beach, Pulau Pinang. The highest isolates found were belonged to Fusarium genera. They stated that soil microfungi would prefer locations that contain high organic matter content like plant roots as their habitat. Hence, Tanjung Aru Beach and Balok Beach probably did not contain enough organic matter for the growth of Fusarium species as there were no isolates found from both beach samples.

The least isolates of fungal species were identified as Bipolaris species and Chaetomium species which were obtained from Chenang Beach, Kedah. In Malaysia, there are no reports on Bipolaris species isolated from sandy beach soil; nevertheless, Kusai et al. (2015) had carried out a study on Curvularia and related species associated with leaf spot disease of rice in Peninsular 
Malaysia. They found 33 isolates identified as Bipolaris sorokiniana, whereas others as Curvularia species. Moreover, Ashok et al. (2015) discovered Bipolaris species, which was isolated from coastal area of Tuticorin Dt., Tamil Nadu, and India. Similar to Bipolaris species, there are no study done on Chaetomium in Malaysia. Nonetheless, Migahed (2003) done a study on "Distribution of Fungi in the Sandy Soil of Egyptian Beaches", which isolated fungi from nine different localities in Egypt. Four highest genera found by the study were Chaetomium, Penicillium, Aspergillus and Trichoderma, respectively.

The size of ITS band amplified in DNA of Bipolaris species was at $575 \mathrm{bp}$ compared to the study done by Peterson \& Balbalian (2010), which was 572 bp of sequence for Bipolaris isolates using primer ITS1 and ITS4. Based on phylogenetic tree constructed, all the genera were classified based on their classes as each of genus in the same subclades. In subclade A on A1, all of the Aspergillus species and Penicillium species were successfully classified on the same branch of same species. However, there were mixed-up between the sequence of branching for Penicillium species and Aspergillus species. This shows that these two genera have a high similarity in terms of ITS sequence since these two genera came from the same class. In addition, these two genera were difficult to be differentiated as both genera have quite a similarity in their morphological. Volk (2010) mentioned that there were difficulty for distinguishing between genera Aspergillus and Penicillium species. Therefore, differentiating both genera was done based on their shapes and arrangements of their conidia on their conidiophores. In a study done by Castrillo et al. (2012) on "Taxonomy and phylogenetic analysis of Aspergillus section Nigri isolated from Yerba Mate in Misiones (Argentina)", they had constructed phylogenetic tree of Aspergillus species with Penicillium species included in the same subclade of Aspergillus species.

Moreover, Chaetomium species was included in subclade B on B1. The bootstrap value showed 99\% similarities between subclades B1 and B2. This shows that there were high similarities between Chaetomium species, Fusarium species and Trichoderma species as three of these genera were classified in the same class. Ning \& Sung (2008) mentioned that Sordariomycetes is one of the largest classes in the Ascomycota where the majority members of this class produced perithecial ascomata. Next, Fusarium species and Trichoderma species were classified in the same subclade, which is B2 with high bootstraps percentage (94\%). Bipolaris species was classified in clade II as it is the only one in class Dothideomycetes.

Microfungal is one of the success nature decomposers that can turn into a success pathogenic organism based on myriads reports of devastating lost in crops and human health. Microfungi were listed as one of the pathogenic microbes in sandy beach (World Health Organization Geneva 2003, Solo-Gabriele et al. 2015). The term pathogenic fungal and opportunistic or potentially pathogenic fungi and mycoses are very familiar to fungi. Pathogenic fungi are referred to the fungi that cause disease under normal condition. Meanwhile, opportunistic or potentially pathogenic fungi are fungi that cause disease when opportunities exist such as in immunocompromised individual. Mycoses is a term related to fungal infection to animals including human (Farlex Partner Medical Dictionary 2012). Microfungi are in their resting state in a form of dormant spore or fragment of mycelia in beach sand. Human activities and the substrate they leave at sandy beach are one of the sources of organic matter that will be degraded by microfungal other than wood debris and dead materials from marine and terrestrial organisms. Due to that, a concern on health risk had arisen among beachgoers.

Although the renowned dermatophyte fungus from genera such as Microsporum sp. and Trychophyton sp. commonly isolated from sandy beach were not recovered in this study and the numbers of mycosis cases in sandy beach were not frequently reported in sandy beach, optimist precautions should be considered especially for the beachgoers. This is important to prevent severe infection disease from opportunistic fungi including Aspergillus sp. On the other hand, long and direct exposure to microbes including microfungi in sandy beach sand in which dermal contact, eye and ear contact, inhalation and ingestion can be a route for the transmission of infectious diseases (Solo-Gabriele et al. 2015). 


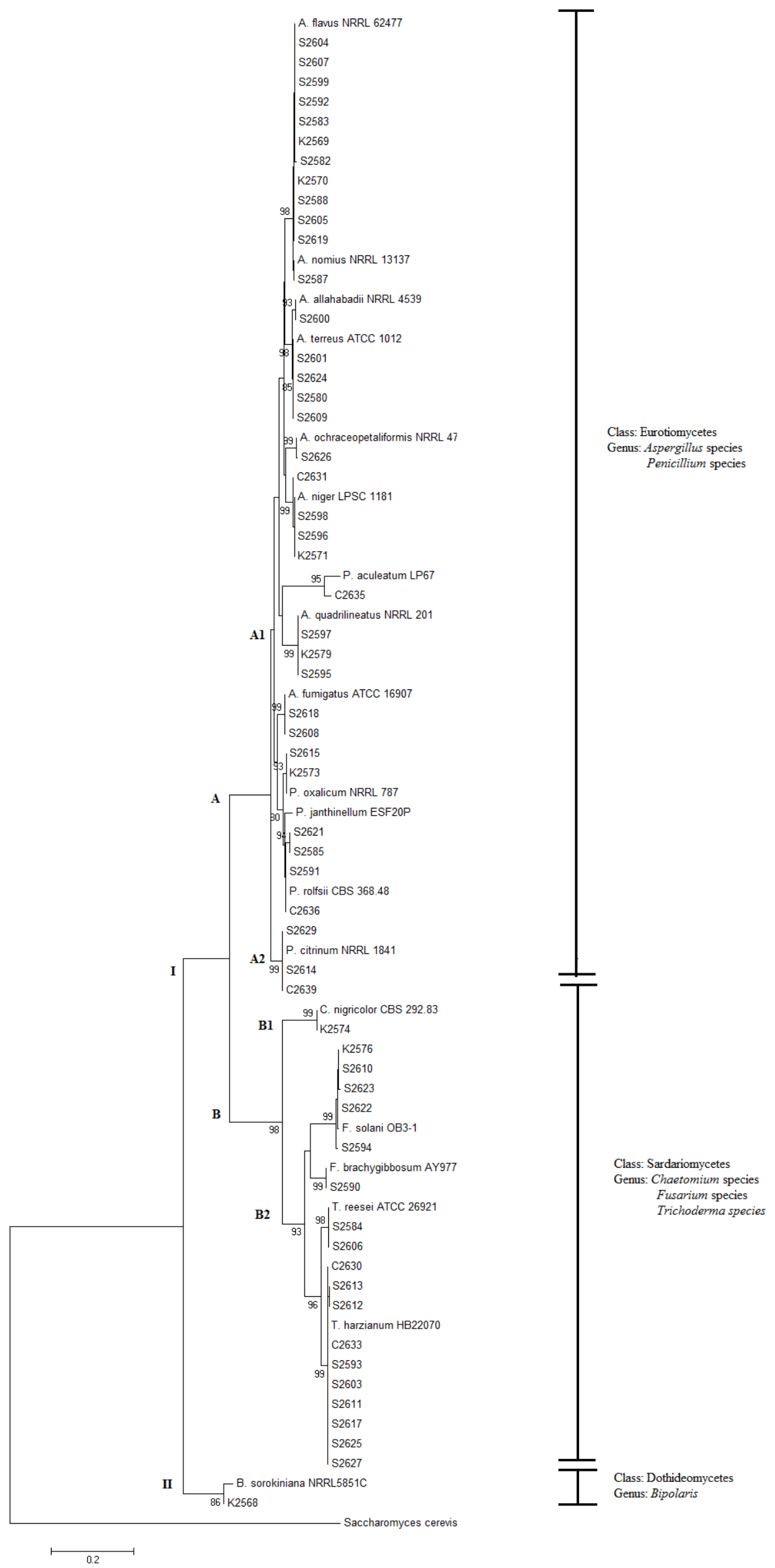

Fig. 4 - Maximum likelihood tree of 57 isolates of Ascomycetes fungi based on ITS sequence analysis. Saccharomyces cerevisiae is an outgroup. 


\section{Acknowledgements}

The authors would like to thank Mrs. Nor Hidayah Husain, Munirah Mohd Sattar, Sharifah Siti Maryam Syd Abdul Rahman and Nur Baiti Abd Murad for technical assistance.

\section{References}

Ashok G, Senthilkumar G, Panneerselvam A. 2015 - Original research article diversity and seasonal variation of soil fungi isolated from coastal area of Tuticorin Dt., Tamil Nadu, India. International Journal Current Microbiology Application Science, 4(10), 161-178.

Asis A, Siddiquee S. 2016 - Identification of Trichoderma Species from wet paddy field soil samples. Transactions on Science and Technology Journals, 11(1), 1-7.

Blanchet G. 2014 - Neighbor Joining or Maximum Likelihood. Retrieved from https://www.researchgate.net/post/Neighbor_joining_or_maximum_likelihood

Bokulich NA, Bamforth CW. 2017 - Brewing Microbiology: Current Research, Omics and Microbial Ecology. Aspergillus. Caister Academic Press Publishing. [Adobe Digital Editions version]. doi: 10.21775/9781910190616

Castrillo ML, Fonseca MI, Bich GA, Jerke G et al. 2012 - Taxonomy and phylogenetic analysis of Aspergillus section Nigri isolated from Yerba Mate in Misiones (Argentina). Journal of Basic and Applied Genetics, 23(2), 19-27.

Farlex Partner Medical Dictionary. 2012 - Mycoses. Retrieved November 29, 2016, from The free dictionary: http://medical-dictionary.thefreedictionary.com/mycoses

Kumar S, Stecher G, Tamura K. 2016 - MEGA7: Molecular evolutionary genetics analysis version 7.0 for bigger datasets. Molecular Biology Evolution, 33(7), 1870-4.

Kusai NA, Azmi MMZ, Zulkifly S, Yusof MT, Nur Ain Izzati MZ. 2015 - Morphological and molecular characterization of Curvularia and related species associated with leaf spot disease of rice in peninsular Malaysia. Rend. Accademia Nazionale Dei Lince, 27, 205-214.

Leslie JF, Summerell BA. 2006 - The Fusarium Laboratory Manual. Blackwell Publishing, Hoboken, 1-2. Retrieved from https://doi.org/10.1002/9780470 278376

Migahed FF. 2003 - Distribution of Fungi in the Sandy Soil of Egyptian Beaches. Pakistan Journal of Biological Sciences, 6(2), 860-866.

Ning Z, Sung GH. 2008 - Sordariomycetes. The Tree of Life Web Project. Retrieved from http://tolweb.org/Sordariomycetes/29050/2008.01.14 in The Tree of Life Web Project

Peterson MT, Balbalian CJ. 2010 - First report of Bipolaris oryzae causing leaf spot of switchgrass in Mississippi. APS Journals, 94 (5), 643-651.

Powell KA, Renwick A, Peberdy JF. 1994 - The Genus Aspergillus from Taxonomy and Genetics to Industrial Application. Plenum Press Publishing.

Sabino R, Rodrigues R, Costa I, Carneiro C et al. 2014 - Routine screening of harmful microorganisms in beach sands: Implications to public health. Science of the Total Environment, 472, 1062-1069.

Seelan JSS, Ali AAKF, Muid S. 2009 - Aspergillus species isolated from mangrove forests in Borneo Island, Sarawak, Malaysia. Journal of Threatened Taxa, 1(6), 344-346.

Solo-Gabriele HM, Harwood VJ, Kay D, Fujioka RS et al. 2015 - Beach sand and the potential for infectious disease transmission: observations and recommendations. Journal of the Marine Biological Association of the United Kingdom, 96(1), 1-20.

Teh LY, Latiffah Z. 2013 - A new record of Penicillium pimiteouiense from beach soil in Malaysia. The Korean Society of Mycology, 41(4), 256-259.

Teh LY, Latiffah Z. 2015 - Occurrence and molecular characterization of Aspergillus species in beach sand. Malaysian Applied Biology, 44(2), 119-127.

Volk T. 2010 - Aspergillus. Retrieved from Department of Biology of University of Wisconsin-LaCrosse website: http://botit.botany.wisc.edu/toms_fungi/feb97.html

White TJ, Bruns T, Lee S, Taylor J. 1990 - Amplification and direct sequencing of fungal ribosomal RNA genes for phylogenies. In: Innis MA, Gelfand DH, Sninsky JJ, White TJ. 
(eds) PCR Protocols: A Guide to Methods and Applications. Academic Press, San Diego, 315-322.

World Health Organization Geneva. 2003 - Chapter 6: Microbial aspects of beach sand quality. In Guidelines for safe recreational water environments (pp. 118-127). World Health Organization 2003.

Yee TL, Zakaria L. 2014 - The First Report of Penicillium georgiense in Malaysia. The Korean Society of Mycology, 42(3), 274-278.

Zakaria L, Yee TL, Zakaria M, Salleh B. 2011 - Diversity of microfungi in sandy beach soil of Teluk Aling, Pulau Pinang. Tropical Life Sciences Research, 22(1), 71-80. 